\title{
Thyroid and pituitary thyroxine-5'-deiodinase activity and thyrotrophin secretion in lithium-treated rats
}

\author{
T G P Frankenfeld, V M Corrêa da Costa, C C A Nascimento-Saba ${ }^{1}$, \\ T M Ortiga-Carvalho, R M M Santos, P C Lisboa ${ }^{1}$, D P Carvalho \\ and D Rosenthal
}

Laboratório de Fisiologia Endócrina, Instituto de Biofísica Carlos Chagas Filho, Universidade Federal do Rio de Janeiro, Centro de Ciencias da Saude, Cidade
Universitária, 21949.900-Rio de Janeiro, Brasil
'Depto Ciências Fisiológicas, Instituto de Biologia Roberto Alcantara Gomes, Universidade do Estado do Rio de Janeiro 20550.030-Rio de Janeiro,
Brasil
(Correspondence should be addressed to D Rosenthal; Email: doris@biof.ufrj.br)
(Requests for offprints should be addressed to T G P Frankenfeld)

\begin{abstract}
Some authors have reported increased serum thyrotrophin (TSH) in animals chronically treated with lithium, suggesting that lithium might decrease pituitary thyroxine $\left(\mathrm{T}_{4}\right)-5^{\prime}$-deiodinase activity. On the other hand, the effect of lithium treatment on thyroidal $\mathrm{T}_{4}-5^{\prime}$-deiodinase activity is also unknown. The present study was undertaken to evaluate the effects of lithium treatment on pituitary and thyroid $\mathrm{T}_{4}-5^{\prime}$-deiodinase activity. Serum and pituitary TSH levels and thyroidal and pituitary $\mathrm{T}_{4}-5^{\prime}$-deiodinase activities were determined in 3-month-old isogenic male Dutch-Miranda rats treated with lithium for 8 weeks.
\end{abstract}

Chronic lithium treatment produced a slight increase in pituitary TSH content, but no change in serum TSH, and a significant increase in the thyroidal $\mathrm{T}_{4}-5^{\prime}$-deiodinase activity. However, the pituitary $\mathrm{T}_{4}-5^{\prime}$-deiodinase activity was unaffected by lithium administration. As far as we know, the present data show for the first time that chronic lithium treatment can increase the thyroxine to triiodothyronine conversion in the murine thyroid gland, be it directly or indirectly.

Journal of Endocrinology (2002) 174, 331-334

\section{Introduction}

Lithium administration may alter thyroid function directly or indirectly, but the mechanisms involved are still unclear. Some authors have suggested that an important effect of lithium could involve a decrease of the peripheral metabolism of thyroid hormones in humans (Carlson et al. 1973) and rats (Voss et al. 1977). A direct inhibitory effect of lithium on the murine pituitary type II thyroxine- $5^{\prime}-$ deiodinase was also referred to by St Germain (1987). The conversion of thyroxine $\left(\mathrm{T}_{4}\right)$ to $3,3^{\prime}, 5^{\prime}$-triiodothyronine $\left(T_{3}\right)$ in the pituitary has been shown to be of primordial importance for the negative feedback of thyroid hormones on thyrotrophin (TSH) secretion (Silva et al. 1978). Several studies have shown that the rat pituitary tissue contains both the propylthiouracil (PTU)-sensitive type I iodothyronine-deiodinase activity (DI-I), similar to that found in liver and kidney, and the PTU-insensitive type II iodothyronine-deiodinase activity (DI-II), which seems to account for a high percentage of the total $\mathrm{T}_{4}$ to $\mathrm{T}_{3}$ conversion in the pituitary gland (Van Doorn et al. 1983, Visser et al. 1983).
Some authors have previously found increased TSH secretion in humans during lithium treatment (Lauridsen et al. 1974, Maarbejerg et al. 1987, Deodhar et al. 1999). We have previously shown that thyroid hormone serum levels, thyroperoxidase activity and the 24-h thyroid radioiodide uptake were unchanged after chronic lithium treatment in rats (Frankenfeld et al. 1992), but a possible transitory effect of lithium on TSH secretion or a direct effect on pituitary thyroxine- $5^{\prime}$-deiodinase $\left(\mathrm{T}_{4}-5^{\prime}-\mathrm{DI}\right)$ activity have not yet been evaluated. In rats, the thyroid gland is a major source of circulating $\mathrm{T}_{3}$ (Chanoine et al. 1993), in part through intraglandular $\mathrm{T}_{4}$-deiodination by type I DI, that might also be affected by chronic lithium use.

In order to better evaluate the effects of chronic lithium treatment in rats, in this study we evaluated the thyroid and pituitary thyroxine $5^{\prime}$-deiodinase activities as well as the pituitary TSH content and serum TSH, since it is known that both the thyroid and the pituitary glands concentrate lithium (Berens et al. 1970, Nelson et al. 1976, Frankenfeld et al. 1992). 


\section{Materials and Methods}

\section{Animals and hormone measurements}

The study protocol was approved by the Institutional Use of Animals in Research Committee (CAUAP, IBCCF), and the procedures used are in compliance with the International Guiding Principles for Biomedical Research Involving Animals, CIOMS/Switzerland, and the guiding principles for Care and Use of Animals from the American Physiological Society.

Isogenic male Dutch-Miranda rats, 3 months old, maintained in a temperature-controlled room $\left(22-25^{\circ} \mathrm{C}\right)$ with a ratio of $12 \mathrm{~h}$ light: $12 \mathrm{~h}$ darkness, were randomly divided into experimental and control groups of three animals each. During the following 8 weeks the experimental groups received $12.5 \mathrm{mM} \mathrm{LiCl}$ in the drinking water, while the paired control groups received tap water. Pelleted commercial animal chow (Purina) was offered ad libitum. We used two experimental protocols: (A) blood samples were collected from the jugular vein every week, for serial determinations of serum $\mathrm{T}_{4}, \mathrm{~T}_{3}$ and $\mathrm{TSH}$, and (B) at the end of the experimental period blood was collected from the jugular vein, the animals were killed under ether, and the thyroid and pituitary glands were rapidly removed. Serum was stored at $-20^{\circ} \mathrm{C}$. For the pituitary gland TSH determination, individual glands were homogenised in $500 \mu \mathrm{l}$ ice-cold phosphosaline buffer, $\mathrm{pH}$ $7 \cdot 6$, containing $1 \%$ bovine serum albumin; the homogenates were stored at $-20{ }^{\circ} \mathrm{C}$ until TSH determination. Serum and pituitary TSH were determined by a specific RIA using a kit for rat TSH determination supplied by the National Hormone and Peptide Program/NIDDK (Bethesda, MD, USA), and was expressed in terms of the preparation provided (RP-1 in the serial experiments (A) and RP-2 for pituitary TSH and serum TSH in the 8-week lithium-treated rats (B)). Serum $\mathrm{T}_{4}$ and $\mathrm{T}_{3}$ were measured by RIA (Mallinckrodt, St Louis, MO, USA). For the deiodinase assays, the thyroid and pituitary glands were rapidly excised, weighed, pooled (six glands per pool) and stored at $-70{ }^{\circ} \mathrm{C}$ for a maximum period of $48 \mathrm{~h}$.

\section{$T_{4}-5^{\prime}$-deiodinase activity assay}

Minor modifications of previously described methods were used for determination of thyroid and pituitary $\mathrm{T}_{4}-5^{\prime}-$ deiodinase activities (Costa \& Rosenthal 1996, Costa et al. 2001). The pooled thyroid glands were homogenised in $50 \mathrm{mM}$ Tris- $\mathrm{HCl}$ buffer, $\mathrm{pH} 7 \cdot 4$, containing $250 \mathrm{mM}$ sucrose and $5 \mathrm{mM}$ dithiothreitol (DTT). The pooled pituitaries were homogenised in $50 \mathrm{mM}$ Tris- $\mathrm{HCl}$ buffer, pH $7 \cdot 6$, containing $250 \mathrm{mM}$ sucrose and $10 \mathrm{mM}$ DTT. The homogenates were centrifuged at $12000 \mathrm{~g}\left(4^{\circ} \mathrm{C}\right.$, $20 \mathrm{~min})$. The supernatant was centrifuged twice at $100000 \mathrm{~g}\left(4^{\circ} \mathrm{C}, 60 \mathrm{~min}\right)$, and the washed pellet was taken up in homogenising buffer without sucrose. The micro- somal fractions were diluted to a protein concentration of 20-50 $\mu \mathrm{g}$ protein $/ 100 \mu \mathrm{l}$ for the thyroid and to $50-80 \mu \mathrm{g}$ protein $/ 100 \mu \mathrm{l}$ for the pituitary gland. Propylthiouracil (PTU, $1 \mathrm{mM}$ ) was added to one of the pituitary microsomal fraction aliquots to inhibit DI-I activity. Protein concentration was determined by the method of Bradford (1976).

The deiodinase assay mixture contained $100 \mu \mathrm{l}$ microsomal fraction and $2 \mu \mathrm{M} \mathrm{T}_{4}$ in a final volume of $125 \mu \mathrm{l}$, and was incubated at $37^{\circ} \mathrm{C}$, for $20 \mathrm{~min}$ in the thyroid DI assays, and for $60 \mathrm{~min}$ in the pituitary DI assays. The reaction was stopped by the addition of $250 \mu \mathrm{l}$ ice-cold $95 \%$ ethanol. The tri-iodothyronine formed was determined in the alcoholic extracts by a specific RIA, as previously described (Costa \& Rosenthal 1996). The $T_{4}-5^{\prime}$-deiodinase activity was expressed as picomoles $T_{3}$ formed per milligram protein ( $\mathrm{pmol} \mathrm{T}_{3} / \mathrm{mg}$ protein). The pituitary type I DI activity was estimated from the difference between total and type II DI activities in the presence of PTU.

\section{Statistical analysis}

The deiodinase activity results are expressed as means \pm S.E.M. Serum TSH values were analysed after logarithmic transformation. Analysis of variance, randomised block experimental design, complemented by multiple comparison tests when adequate, were used for the data statistical evaluation (SuperANOVA program, Abacus Concept, Berkeley, CA, USA).

\section{Results}

As previously reported (Frankenfeld et al. 1992) no signs indicative of toxic effects were seen during the 8-week period of lithium administration.

Pituitary TSH content is increased although not significantly in the lithium-treated animals, but no change in serum TSH was detected during the experimental period (protocol A; Table 1) or at the end of lithium treatment (protocol B; Table 2). No significant differences were found in the serial measurements of serum $T_{4}$ and $T_{3}$ in the lithium-treated rats (Table 1).

Thyroid $\mathrm{T}_{4}-5^{\prime}$-deiodinase activity was significantly increased in the lithium-treated rats $(P<0 \cdot 005)$. Only a slight and not significant increase in type I deiodinase activity was detected in the pituitary, while the type II deiodinase activity was unaffected (Fig. 1).

\section{Discussion}

Goiter and hypothyroidism have been reported to occur occasionally during chronic lithium treatment (Schou et al. 1968, Leppaluoto et al. 1973, Kusalic \& Engelsmann 
Table 1 Serial measurements of serum TSH, $\mathrm{T}_{4}$ and $\mathrm{T}_{3}$ in chronically lithium-treated rats (protocol A). TSH concentrations are expressed in terms of the RP- 1 preparation provided by the National Hormone and Peptide Program/NIDDK. Results were analysed after logarithmic transformation and are shown as means and, within parentheses, limits defined by mean \pm S.E.M. $\mathrm{T}_{4}$ and $\mathrm{T}_{3}$ results are expressed as means \pm S.E.M. The values are means of at least five different animals.

\begin{tabular}{|c|c|c|c|}
\hline & $\begin{array}{l}\text { TSH } \\
(\mathrm{ng} / \mathrm{ml})\end{array}$ & $\begin{array}{l}\mathbf{T}_{\mathbf{4}} \\
(\mu \mathrm{g} / \mathrm{dl})\end{array}$ & $\begin{array}{l}\mathbf{T}_{3} \\
(\mathrm{ng} / \mathrm{dl})\end{array}$ \\
\hline Basal & $\begin{array}{c}2 \cdot 72 \\
(2 \cdot 65-2 \cdot 81)\end{array}$ & $3 \cdot 23 \pm 0 \cdot 14$ & $107 \cdot 60 \pm 10 \cdot 23$ \\
\hline 1 week & $\begin{array}{c}3 \cdot 05 \\
(2 \cdot 88-3 \cdot 23)\end{array}$ & $2 \cdot 80 \pm 0 \cdot 33$ & $118 \cdot 30 \pm 8 \cdot 23$ \\
\hline 2 weeks & $\begin{array}{c}2 \cdot 81 \\
(2 \cdot 63-3 \cdot 02)\end{array}$ & $3 \cdot 54 \pm 0 \cdot 12$ & $107 \cdot 00 \pm 7 \cdot 03$ \\
\hline 3 weeks & $\begin{array}{c}2 \cdot 90 \\
(2 \cdot 80-3 \cdot 00)\end{array}$ & $2 \cdot 63 \pm 0 \cdot 29$ & $100 \cdot 70 \pm 6 \cdot 77$ \\
\hline 4 weeks & $\begin{array}{c}3 \cdot 32 \\
(3 \cdot 15-3 \cdot 51)\end{array}$ & $3 \cdot 37 \pm 0 \cdot 33$ & $98 \cdot 14 \pm 11 \cdot 05$ \\
\hline 5 weeks & $\begin{array}{c}3 \cdot 16 \\
(3 \cdot 00-3 \cdot 34)\end{array}$ & $3 \cdot 04 \pm 0 \cdot 38$ & $100 \cdot 10 \pm 2 \cdot 98$ \\
\hline 6 weeks & $\begin{array}{c}3 \cdot 10 \\
(2 \cdot 96-3 \cdot 52)\end{array}$ & $4 \cdot 18 \pm 0 \cdot 10$ & $68 \cdot 40 \pm 6 \cdot 07$ \\
\hline 8 weeks & $\begin{array}{c}3 \cdot 20 \\
(3 \cdot 09-3 \cdot 33)\end{array}$ & $3 \cdot 83 \pm 0 \cdot 12$ & $110 \cdot 70 \pm 6 \cdot 92$ \\
\hline
\end{tabular}

1999). Several mechanisms have been proposed to explain lithium effects on thyroid function (Lazarus 1998, Sigrid et al. 2000). It has been suggested that, in humans, lithium might have a direct inhibitory action on thyroid hormone secretion, which might result in a compensatory increase in serum TSH (Sedvall et al. 1969, Spaulding et al. 1972). Various studies have reported sub-clinical hypothyroidism associated with increased serum TSH and/or TSH response to exogenous thyrotrophin-releasing hormone in patients treated with lithium (Lazarus 1998, Kliner et al. 1999).

In previous studies we found no significant changes in 24-h thyroid radioiodide uptake, thyroid radiolabelled iodoamino acids content, thyroid peroxidase activity or serum $\mathrm{T}_{3}$ and $\mathrm{T}_{4}$ in chronically lithium-treated rats

Table 2 Serum and pituitary TSH in control and chronically lithium-treated rats at the end of the treatment period (protocol B). $\mathrm{TSH}$ concentrations are expressed in terms of the RP-2 preparation provided by the National Hormone and Peptide Program/NIDDK. Results were analysed after logarithmic transformation and are shown as means and, within parentheses, limits defined by mean \pm S.E.M.

\begin{tabular}{|c|c|c|c|}
\hline & $n$ & Control & Lithium \\
\hline Serum TSH (ng/ml) & 10 & $\begin{array}{l}0.82 \\
(0 \cdot 74-0 \cdot 90)\end{array}$ & $\begin{array}{l}0 \cdot 88 \\
(0 \cdot 80-0.96)\end{array}$ \\
\hline Pituitary TSH ( $\mu \mathrm{g} / \mathrm{g})$ & 8 & $\begin{array}{l}7 \cdot 93 \\
(7 \cdot 18-8 \cdot 77)\end{array}$ & $\begin{array}{l}10 \cdot 67 \\
(9 \cdot 75-11 \cdot 67)\end{array}$ \\
\hline
\end{tabular}

www.endocrinology.org
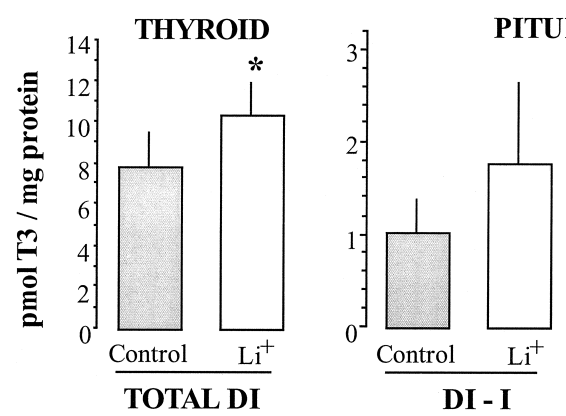

PITUITARY

Figure 1 Thyroid and pituitary $\mathrm{T}_{4}-5^{\prime}$-deiodinase activities at the end of the treatment period in control and chronically lithium-treated rats. ${ }^{*} P<0 \cdot 05$ compared with controls.

(Frankenfeld et al. 1992). These observations suggested that chronic lithium effects on murine thyroid glands were either irrelevant or minimised by increased thyroid stimulation by TSH. Child et al. (1976) reported a transient decrease in serum $\mathrm{T}_{3}$ or $\mathrm{T}_{4}$ in lithium-treated rats during the second and third weeks of treatment. Although serum TSH was not determined in their study, the fact that goiter appeared during the third and fourth weeks of treatment, and that serum thyroid hormones returned to normal levels during the fourth week, are consistent with an increment of TSH effects on the thyroid gland. In the present study, we found no expressive changes in serum TSH levels during the whole period of lithium treatment.

The thyroid and the pituitary glands concentrate lithium (Berens et al. 1970, Nelson et al. 1976, Frankenfeld et al. 1992). A direct in vitro inhibitory effect of lithium on renal DI-I activity has been reported by Mannisto (1974), but St Germain (1987) found no acute change in kidney DI activity in vivo after lithium injection.

A significant inhibitory effect of lithium on the type II deiodinase activity has been found in cultured pituitary and neural tissues by St Germain (1987), and a decreased type II deiodinase activity was also found in several brain regions of rats treated with lithium for 14 days (Baumgartner et al. 1997). Nevertheless, we found no significant differences in type I or type II pituitary $\mathrm{T}_{4}-5^{\prime}$-deiodinase activities in chronically lithium-treated rats. It is interesting to note that acute toxic doses of lithium also failed to produce detectable effects on serum TSH or on the hypothalamic or pituitary D-II activity (Eravci et al. 2000). Thus, different doses and/or periods of treatment may be responsible for the apparent discrepancy between the various studies.

A significantly enhanced thyroidal $\mathrm{T}_{4}-5^{\prime}$-deiodinase activity in long-term lithium-treated rats was found in the present study. The increase of in vivo thyroidal DI-I activity was also found after only 2 weeks of lithium treatment, using an alternative methodology (results not shown, Frankenfeld et al. 2001). As far as we know, these are the first reports of in vivo lithium effects on thyroid 
gland $\mathrm{T}_{4}-5^{\prime}$-deiodinase activity. The increased thyroidal DI activity suggests an enhanced TSH effect on the thyroid, even if the serum TSH is not increased, since $\mathrm{TSH}$ is the major regulator of $\mathrm{T}_{4}$ deiodination in the thyroid gland (Erickson et al. 1982). Nevertheless, a direct lithium effect on the thyroidal deiodinases cannot be discarded. These hypotheses must be further tested. Further studies on the chronic effects of lithium on the thyroid-pituitary axis are still necessary until we completely understand how this cation can change thyroid gland function and regulation.

\section{Acknowledgements}

Thanks are due to Advaldo N Bezerra, Norma L A Farias and Wagner $\mathrm{N}$ Bezerra for excellent technical assistance. This research was supported in part by FINEP, CEPG/ UFRJ and CNPq.

\section{References}

Baumgartner A, Pinna G, Hiedra L, Gaio U, Hessenius C, CamposBarros A, Eravci M, Prengel H, Thoma R \& Meinhold H 1997 Effects of lithium and carbamazepine on thyroid hormone metabolism in rat brain. Neuropsychopharmacology 16 25-41.

Berens SC, Wolff J \& Murphy DL 1970 Lithium concentration by the thyroid. Endocrinology 87 1085-1087.

Bradford MM 1976 A rapid and sensitive method for the quantitation of microgram quantities of protein utilizing the principle of protein-dye binding. Analytical Biochemistry 72 248-254.

Carlson HE, Temple R \& Robbins J 1973 Effect of lithium on $T_{4}$ disappearance in man. Journal of Clinical Endocrinology and Metabolism 36 1251-1254.

Chanoine J, Braverman LE, Farwell AP, Marjorie S \& Sharon A 1993 The thyroid gland is a major source of circulating $\mathrm{T}_{3}$ in rat. Journal of Clinical Investigation 91 2709-2713.

Child C, Nolan G \& Jubiz W 1976 Changes in serum $T_{3}, T_{4}$ and TSH induced by lithium in normal subjects and rats. Clinical Pharmacology and Therapentics 20 715-719.

Costa VMC \& Rosenthal D 1996 Effect of aging on thyroidal and pituitary $\mathrm{T}_{4}-5^{\prime}$ deiodinase activity in female rats. Life Sciences $\mathbf{5 9}$ $1515-1520$.

Costa VMC, Moreira DG \& Rosenthal D 2001 Thyroid function and aging: gender-related differences. Journal of Endocrinology 171 193-198.

Deodhar SD, Singh B, Pathak CM, Sharan P \& Kulhara P 1999 Thyroid functions in lithium-treated psychiatric patients: a crosssectional study. Biological Trace Element Research 67 151-163.

Eravci M, Pinna G, Meinhold H \& Baumgartner A 2000 Effects of pharmacological and nonpharmacological treatments on thyroid hormone metabolism and concentrations in rat brain. Endocrinology 141 1027-1040.

Erickson VJ, Cavaliere RR \& Rosenberg LL 1982 Thyroxine $5^{\prime}$-deiodinase of rat thyroid, but not liver is dependent on thyrotropin. Endocrinology 111 434-440.

Frankenfeld TGP, Carvalho-Guimarães DP, Breitenbach MMD \& Rosenthal D 1992 Chronic lithium effects on murine thyroid function. Lithium 3 55-59.
Frankenfeld TGP, Lisboa PC, Oliveira KJ, Barros IA, Lima LP, Cabanelas A, Adnet J \& Pazos-Moura CC 2001 Desiodases tireoideanas em ratos tratados aguda e cronicamente com lítio. Arquivos Brasileiros de Endocrinologia e Metabologia 45 (Suppl 1) S56. Latin American Thyroid Society IX Congress (Abstract PO48).

Kliner J, Altshuller L, Hendrick V \& Hershman JM 1999 Lithiuminduced subclinical hypothyroidism: review of the literature and guidelines for treatment. Journal of Clinical Psychiatry 60 249-255.

Kusalic M \& Engelsmann F 1999 Effect of lithium maintenance therapy on thyroid and parathyroid function. Journal of Psychiatry and Neurosciences 24 227-233.

Lauridsen UB, Kirkegaard C \& Nerup J 1974 Lithium and the pituitary thyroid axis in normal subjects. Journal of Clinical Endocrinology and Metabolism 39 383-385.

Lazarus JH 1998 The effects of lithium therapy on thyroid and thyrotropin-release. Thyroid 8 909-1013.

Leppaluoto J, Mannisto PT \& Virkinen P 1973 On the mechanism of goitre formation during lithium treatment in the rat. Acta Endocrinologica 74 296-306.

Maarbejerg K, Vestergaard P \& Schou M 1987 Changes in serum thyroxine $\left(\mathrm{T}_{4}\right)$ and serum thyroid stimulating hormone (TSH) during prolonged lithium treatment. Acta Psychiatrica Scandinavica 75 217-221.

Mannisto PT 1974 Effect of lithium on deiodinating activity of various rat tissues in vitro. Acta Endocrinologica 76 260-272.

Nelson CC, Herman NM \& Bensch KG 1976 Localization and quantification of lithium in rat tissue. Experimental and Molecular Pharmacology 25 38-42.

Ramschak-Schwarzer S, Radkohl W, Stiegler C, Dimai HP \& Leb G 2000 Interactions between psychotropic drugs and thyroid hormone metabolism - an overview. Acta Medica Austriaca 1 8-10

Schou M, Amdisen A, Jensen SE \& Olsen T 1968 Occurrence of goitre during lithium treatment. British Medical Journal 3 710-713.

Sedvall G, Jonsson B \& Petterson V 1969 Evidence of an altered thyroid function in man during treatment with lithium carbonate. Acta Psychiatrica Scandinavica (Suppl) 207 59-66.

Silva JE, Dich TE \& Larsen PR 1978 The contribution of local tissue thyroxine monodeiodination to the nuclear 3,5,3'-tri-iodothyronine in the pituitary liver and kidney of euthyroid rats. Endocrinology 103 1196-1207.

Spaulding SW, Burrow GN, Bermude F \& Himmeloch JM 1972 Inhibitory effect of lithium on thyroid hormone release in both euthyroid and thyrotoxic patients. Journal of Clinical Endocrinology and Metabolism 35 905-911.

St Germain DL 1987 Regulatory effect of lithium on thyroxine metabolism in murine neural and anterior pituitary tissue. Endocrinology 120 1430-1438.

Van Doorn J, Van der Heide D \& Roelfsema F 1983 Sources and quantity of 3,5,3'-triiodothyronine in several tissues of the rat. Journal of Clinical Investigation 72 1778-1792.

Visser TJ, Kaplan MM, Leonard JL \& Larsen PR 1983 Evidence for two pathways of iodothyronine $5^{\prime}$-deiodination in rat pituitary that differ in kinetics, propylthiouracil sensitivity and response to hypothyroidism. Journal of Clinical Investigation 71 992-1002.

Voss CHR, Schober HC \& Hartmann N 1977 Einflus von Lithium auf die in vitro-Dejodierung von L-Thyroxin in der Rattenleber. Acta Biologica et Medica Germanica 36 1061-1065.

Received in final form 21 March 2002

Accepted 24 April 2002 